\title{
スポーツにおける高速ビデオカメラ*
}

\author{
浅井 武**

\section{High speed video camera in sports}

Takeshi AsAI

\section{1.はじめに}

テレビでスポーツ番組を眺めていると，必ずといって いいほど見ることができるのは，ハイライトシーンのス ローモーションである。これは一般的スピード（約 30 fps）の業務用ビデオカメラによる映像をスロー再生し たものと，高速ビデオカメラによる映像を再生したもの とがあるが, 鮮明な画面で詳細にみることができるのは, 勿論, 高速ビデオカメラによる映像である. この高速ビ デオカメラによる映像は, 近年はいろいろな場面で用い られ，スーパースロー等のネーミングでその番組の特徴 の一つになっていたりもする.一般映像ではなかなか捕 らえられない動きや技術をみることができ，スポーツの 専門家でなくても興味深いものである. また, このよう なブロードキャスティングレベルでなくても，高速ビデ オカメラはスポーツに関する研究, 教育, 教材作成 ${ }^{1,2)}$ 等，様々な領域で活用されており，ここではその一部を 紹介したい.

\section{2. スポーツシューズの開発}

スポーツ用具の開発3)では, 現象を記述, 把握したり, 分析するため, 日常的に高速ビデオカメラが用いられて

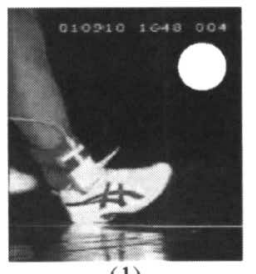

(1)

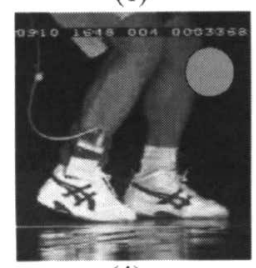

(4)

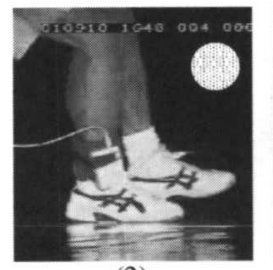

(2)

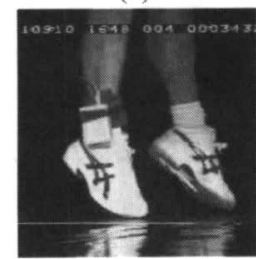

(5)

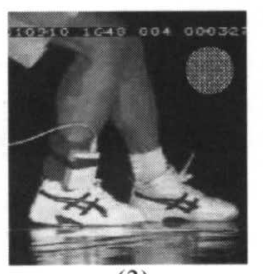

(3)
Fig. 1 An example of jump motion for spike in Volley ball. (ASICS Corp. )

* 原稿受付 2003 年 1 月 16 日

** 山形大学 教育学部
いる.ここでは，スポーツシューズに関する例をとりあ げる. Fig. 1 はバレーボールのスパイク時におけるジャ ンプ動作の高速ビデオカメラ画像である.

また, Fig. 2, Fig. 3 はその時の床反力波形を示して いる. 実際のジャンプ時の足部やシューズの動きは 3 次 元的な複雑な運動を行なうので，床反力計や足圧分布測 定装置, あるいは筋電計等の測定デバイスを目的に応じ て多角的に装着して実験を行なう場合が多い.

この動作の特徴を概観すると, 先ず, 踵から着地し(1), ブレーキ力が最大の時に, 足底全体を用いていることが わかる(2). また, 能動的ジャンプ力を発揮する局面に移

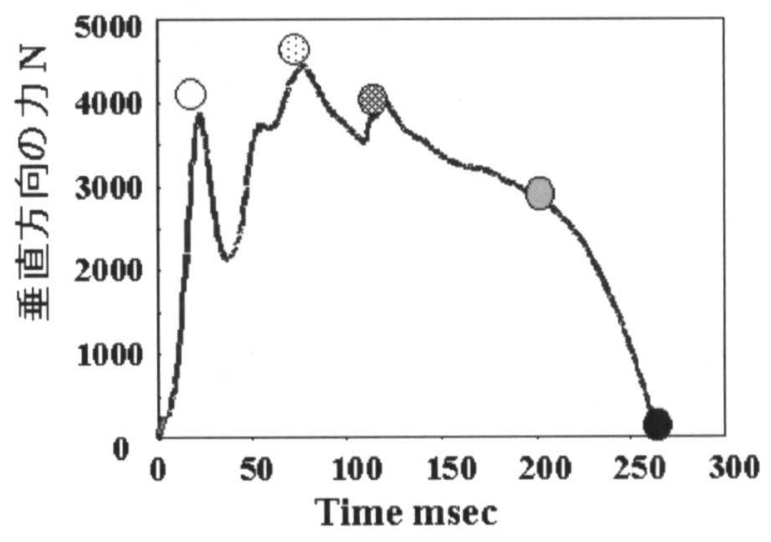

Fig. 2 Vertical ground reaction force in jump motion. (ASICS Corp.)

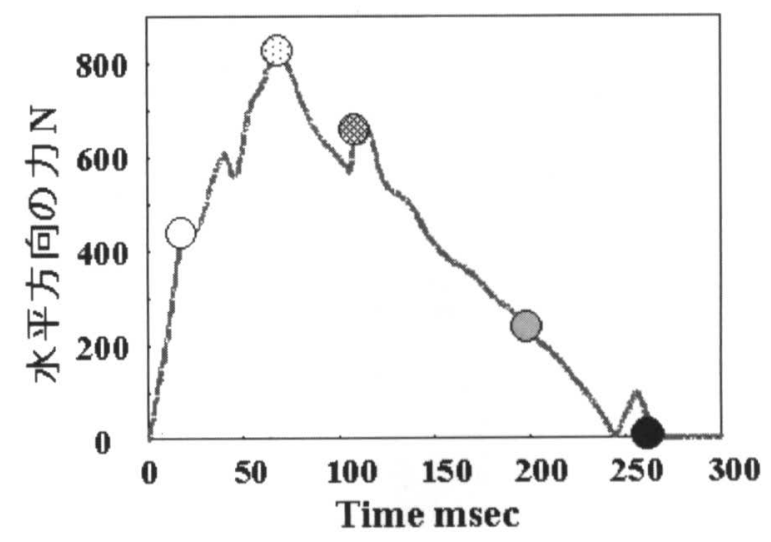

Fig. 3 Horizontal ground reaction force in jump motion. (ASICS Corp. ) 
行するにしたがって，重心の位置が内側よりになり(3), 加速期では, MP 関節（中足骨骨頭部周辺）に大きな力 が働いていることが推察される(4).これらの分析に対応 して, バレーボールシューズのデザインは, 踵部分の緩 衝特性の向上(1), 足底外側部分のブレーキング機能の向 上(2)，重心移動による内側への変形のコントロール(3), MP 関節周辺部分のエネルギーロスの最小化(4)等が重要 となってくるわけである. 勿論, 実際には前述したいろ いろな測定センサーの情報が多角的, かつ総合的に統合 して検討され，最終的に製品に結びついていくのである.

一方, 別の例として, バスケットボールのターン動作 を分析したものがある (Fig. 4). Fig. 5 はその時の床反 力を示している.

バスケットボールは競技特性上, 床でのターン動作が 極めて重要な技術要素となる. 着地時はつま先, 母指球 部側から着地(1), ブレーキ最大時も足底前面が中心と なっている(2). 重心移行期ではかなり大きな大きな横方 向の力が発生しており(3), 加速期では MP 関節に大き な力が働いていることが推定される(4). これらのデータ から, つま先, 母指球部側の接地性の向上(1), 足底前面

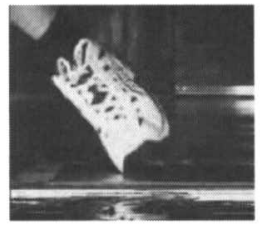

(1)

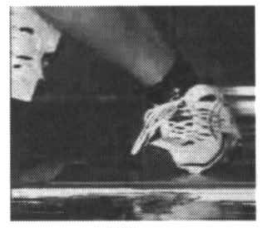

(4)

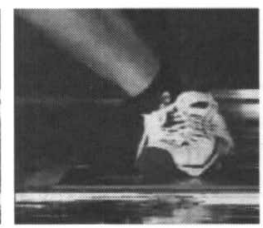

(2)

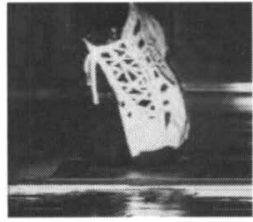

(5)

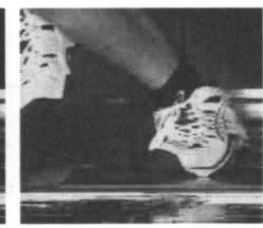

(3)
Fig. 4 An example of turn motion in Basket ball. (ASICS Corp. )

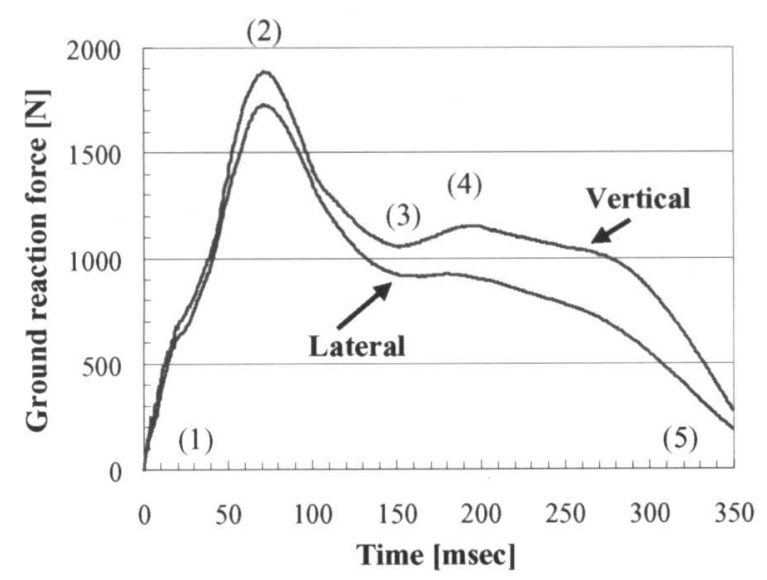

Fig. 5 Grand reaction force in turn motion. (ASICS Corp.)
部の緩衝性の向上(2), 横方向の力に対する変形のコント ロール, ソールの横ずれの抑制(3), MP 関節周辺部分の エネルギーロスの最小化(4)等がデザイン指針としてあげ られよう. したがって, バレーボールのジャンプでは, 踵周辺の緩衝機能が要求されるのに対して, バスケット ボールのターン動作では, 足底部前面の緩衝機能が要求 されるのである.このように同じ体育館で行なわれるス ポーツであっても競技特性によってシューズに要求され る機能は異なり, これに個人の身体能力やクセ, 感性等 が要素として入ってくるので, 高機能シューズの研究開 発というものは, 最先端の多角的知識やノウハウが必要 なハイテク分野であると言える.

また，このような高速度ビデオカメラによる分析と同 時に, その現象のメカニズムの解明や予測, 最適化をね らいとして, コンピュータシミュレーションも並行的に 試みられている. 例えば, 前述のバレーボールのジャン プ動作, バスケットボールのターン動作では, 着地する 部分は異なるが, 加速期では, 共に MP 関節周辺, 特 に母指球サイドに大きな力が発生している傾向がみられ ている.この原因を探っていくため, 足関節の有限要素 骨格モデルを開発し，足関節部外側の剛性と内側の剛性 が比較されている. Fig. 6 は 15 度傾いて足低部外側か ら接触した場合の応力分布を, Fig. 7 は-15 度傾いて足 低部内側から接触した場合の応力分布を示している.

その時の床反力を比較すると, 足関節内側から接触し た場合の方が, 足関節外側から接触した場合より, 素早 く大きな力が発揮されているのがわかる (Fig. 8).これ は, 足関節構造のアライメントや構造特性が原因の一つ になっていると考えられ, 足関節内側の方が外側より剛 性が高く，エネルギーロスが小さいと推定される．この ようなコンピュータシミュレーションによるアプローチ も近年は増加してきており, 現象を正確に記述, 把握す ると言う意味でも，モデルの妥当性を検証するという意 味でも, 今後, 高速度ビデオカメラとの連携が益々重要 になってくるであろう.
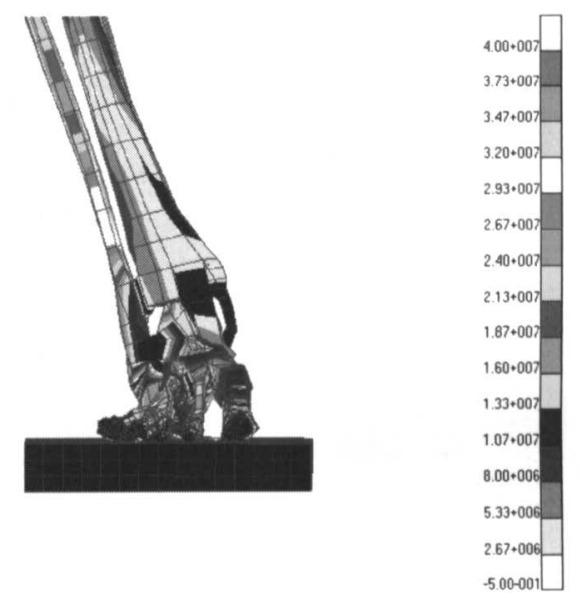

Fig. 6 The stress contours on the deformed shape at outside impact. (front view) 

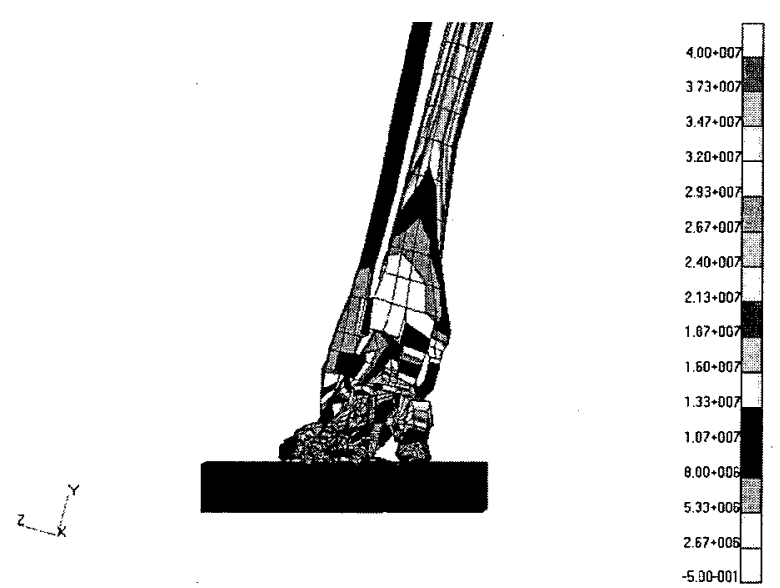

Fig. 7 The stress contours on the deformed shape at inside impact. (front view)

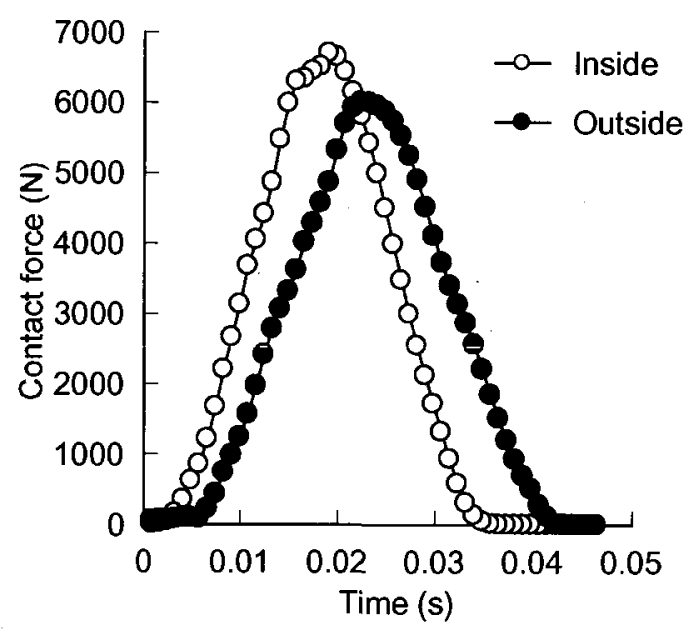

Fig. 8 Comparison of grand reaction force between inside impact and outside impact using computer simulations.

\section{3. サッカーのキックの分析}

スポーツにおける高速ビデオカメラというと，トップ プロスポーツ選手の動作や技術を，2台以上のカメラを

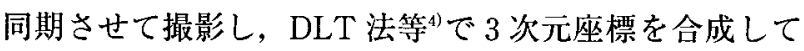
分析するという方法がしばしば用いられる。そして一 度, 3 次元座標值を収集できると, インバースダイナミ クスによって関節トルク ${ }^{5}$ やパワー，筋モーメント等の 検討が可能になる.

例えば，トッププロサッカー選手であるストイコビッ チ選手（元ユーゴスラビア代表）と日本のユース選手の インサイドキックを比較しだ)のが Fig.9である.イン サイドキックというのは足の内側を使ってボールをミ一

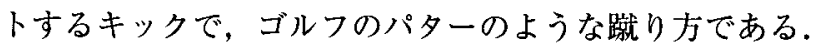
踣り足を外側に捻る（回外）パワーを比較すると，ス卜 イコビッチ選手よりユース選手の方がむしろ大きなパ ワーを出しているのがわかる．蹴り足を振り出すパワー は，ストイコビッチ選手の方が大きく，総合的にユース

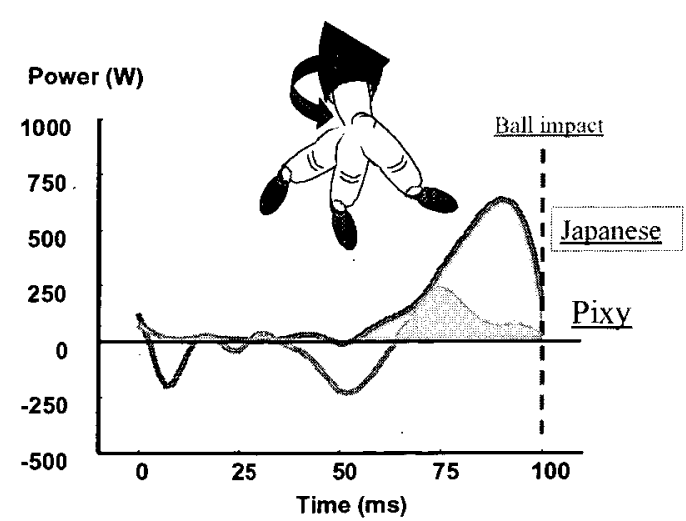

Fig. 9 Comparison of the power in external rotation of kicking leg between top professional player (Pixy) and youth player (Japanese). (Nagoya Univ.)

選手は教科書的な踵を押し出すキック動作を，ストイコ ビッチ選手はよりインステップキックに近いキック動作 をしていることが明らかになった。このストイコビッチ 選手タイプのインサイドキックは足部の運動が回転運動 と並進運動がミックスされると言う意味でコンロールが 難しくなるが，スイングスピードが上げやすい利点があ ると推測され，速いパススピードを要求されるゲーム展 開に適応していると考えられる。また，蹴り足の運動様 式だけで言えば，非力なジュニアサッカー選手のインサ イドキック動作とストイコビッチ選手のインサイドキッ ク動作が似ていたのも興味深い.

また、我々の研究グループは，英国シェフィールド大 学と流体解析ソフト大手のフルーエント社との共同研究 プロジェクトとして，サッカーのカーブキックに関する 研究7).8 を行っている.これは, 実駼等で実際の現象を 把握しようとするだけでなく、コンピュータシミュレー ション技術を活用して，ボール周りの流れやボールの軌 跡を子測し，場合によっては動作や用具等の最適化も試 みていこうというものである.

先ず，ボールスピンを生み出すインパクト過程の分析 として, 高速ビデオカメラ (4500fps；フォトロン株式 会社）を用いた実験と，固体と流体の連成解析を適用し たボールインパクトの衝撃解析を行い，インパクトの瞬 間に拀けるボールとキッカーの足の歪や，ボールスピー ド, 回転数, 摩擦係数の関係等を検討している（Fig. 10 \&Fig. 11).そしてボールの回転には摩擦力同様, オフ セット距離が重要であることや(Fig. 12)，ボールスピー ドをそれ程落とさずにキックするためには，オフセット 距離を小さくする必要があること等が示㖫された (Fig.13).

それらの結果より，実際のフリーキックに扔けるカー ブボールのボール速度は, $25 \sim 30 \mathrm{~m} / \mathrm{s}$ であり, 回転数 は $5 \sim 10 \mathrm{r} / \mathrm{s}$ 程度であると考えられた。

それをうけて，サッカーボールの空力特性に関する煙 風洞実験を行い，一定の速度範囲に扮ける抵抗係数を測 


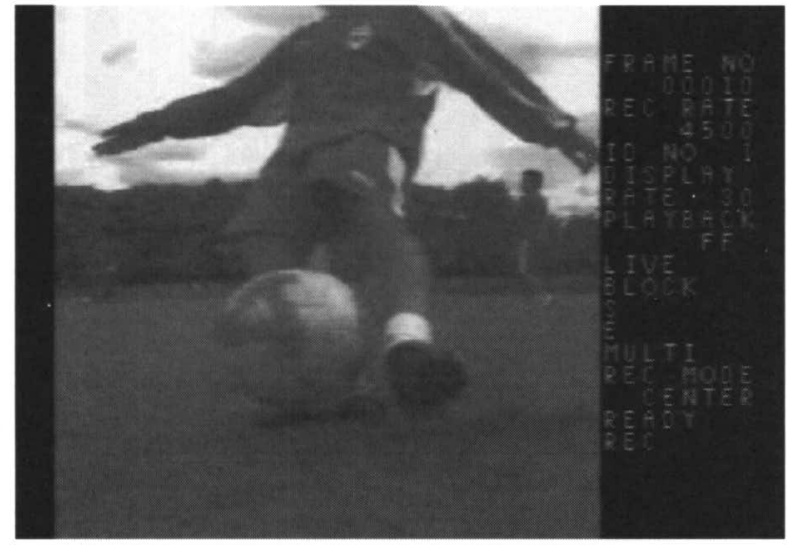

Fig. 10 An example of high speed video image (4500 fps) at impact in curve ball kick.

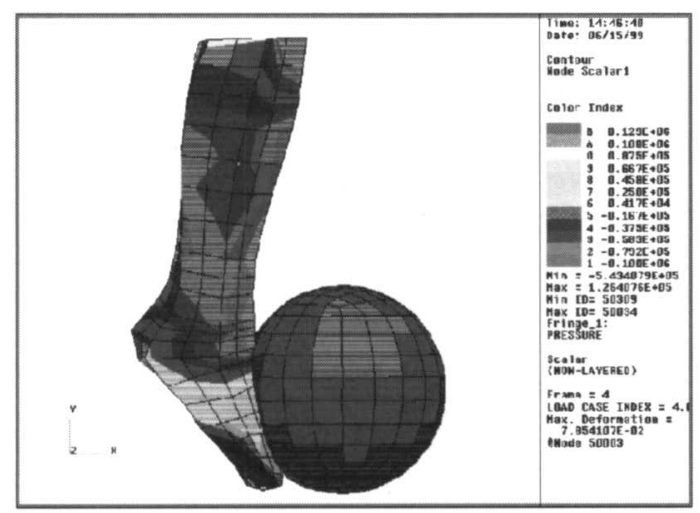

Fig. 11 The pressure contours on the deformed shape at ball impact.

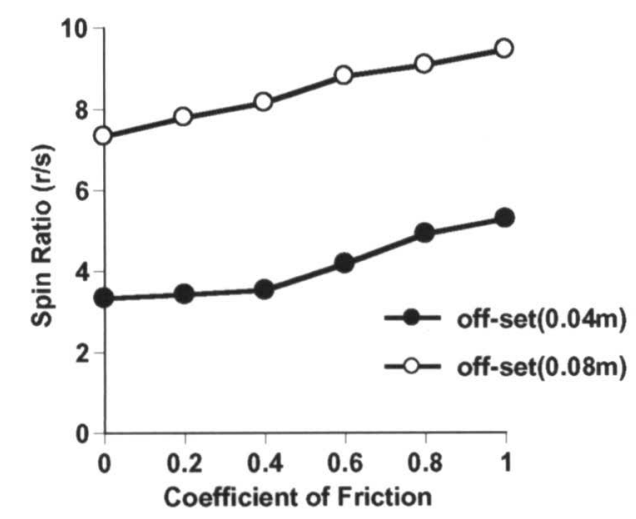

Fig. 12 Relation of coefficient of friction and spin ratio in curve kick simulation.

定した Fig. 14). そして, 本実験環境では, スムース なボールとゴルフボールの中間である，10の 5 乗前後 のレイノルズ数において, ドラッグクライシスが起きる ことが観測された（Fig. 15）。また，類似の条件下で， 数值流体解析ソルバーである Fluent 6.0 を用いてコン ピュータシミュレーションを行い, ボール周りの流れを 可視化すると共に, 変化するボールの軌跡を算出した (Fig. 16). その結果, $25 \mathrm{~m} / \mathrm{s}$ のボールスピードで回転

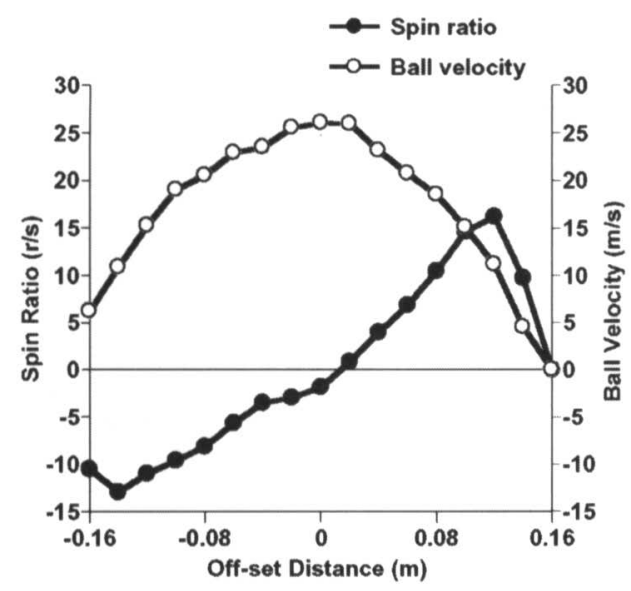

Fig. 13 Relation of offset distance, spin ratio and ball speed in curve kick simulation.

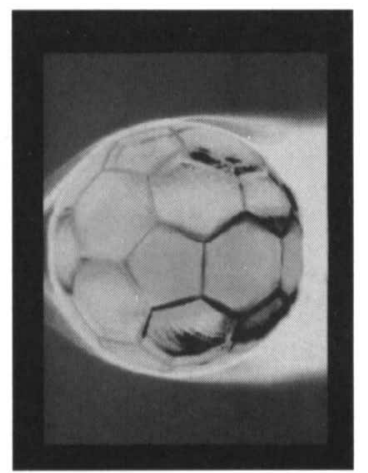

Fig. 14 Wind tunnel experiment about soccer ball. (Sheffield Univ. )

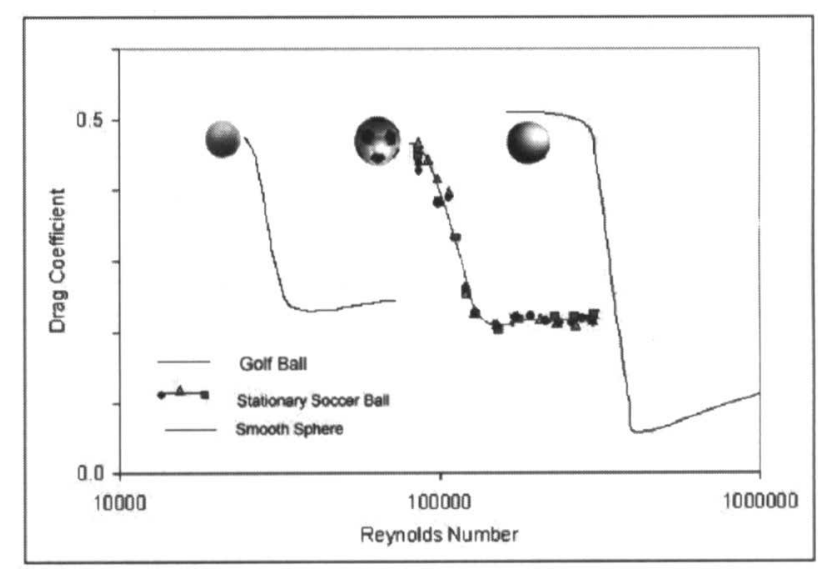

Fig. 15 Drag coefficient of non-spinning soccer bal. (Sheffield Univ. )

数が $50 \mathrm{rad} . / \mathrm{s}$ (毎秒約 8 回転) の場合，インパクト 1 秒後に $3 \mathrm{~m}$ 以上もボールコースが偏向することが示さ れた。

これら一連の研究は, 将来的にはシューズ等のスポー ツ用具の研究・開発や，スポーツ技術の理解や向上に貢 献できると考えている．しかし，現時点では，極めて基 本的段階であり, 課題も多い. 例えば, 回転するサッカー 


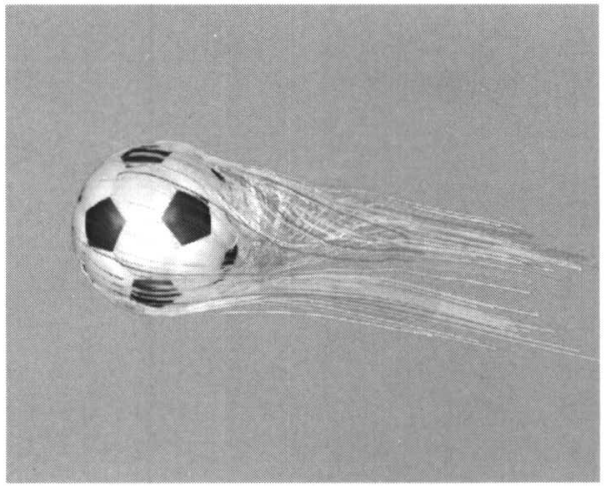

Fig. 16 CFD analysis of soccer ball. (Fluent Inc.)

ボールのドラッグクライシスが起きる臨界レイノルズ数 はよく分かっていない（我々の予備実験では臨界速度が 19-22 m/s ぐらいと推定されたが, 詳細は不明である). また, それが起きたとしても, 回転の両側で同時的に起 きるのか, 片側ずつタイミングが異なるかなど, 問題点 は山積している. 我々の研究グループは, これらの課題 を他の研究グループと複合的にコラボレーションを行な うことによって，一つずつ問題解決していきたいと考え ている. どんなことでも，また，どんな分野の方でも結 構なので, ご批判, ご助言, ご教示を頂けると幸いであ る.

\section{4. 動画データベースと教材作り}

高速ビデオ画像に限らず，動画を扱うとまたたく間に ビデオテープが山積するのが常であり，書棚やビデオ ケースが 8 ミリビデオやVHS 等のテープでうずまって いるのは, 我々の研究室だけではないと思われる。一度 しか使用しないのであれば，倉庫に眠っていても問題は ないが，何度も見返したり，データを取り直したり，他 の教材や資料作成に活用したりと，動画像を再利用する 場合も少なくない. 従来, せいぜい使いそうなビデオテー プを身近な所に置いて, 整理整頓を心がけるといった程 度であったが, 最近, 動画像を自動的にデジタルデータ

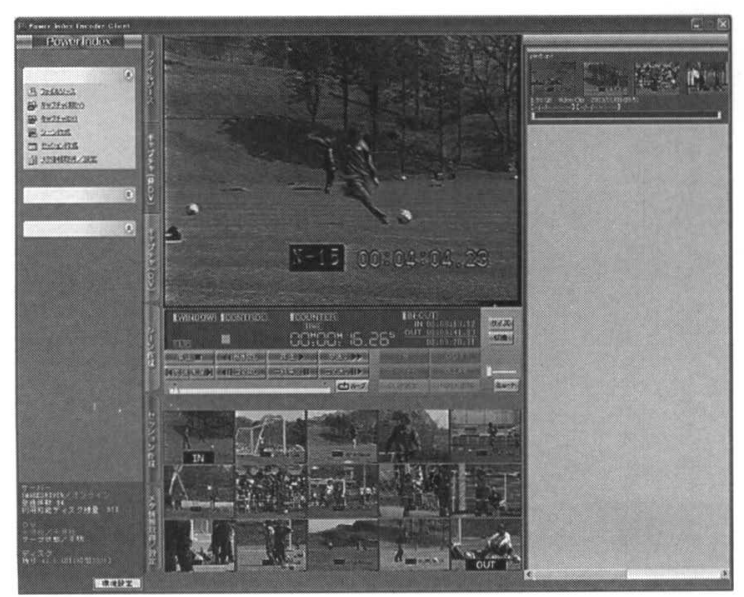

Fig. 17 An example of tool for motion data base. (Power Index ; Photoron Inc.)
としてデータベース化してくれるッールが幾つか出てき ているようである（Fig.17）.

これらのッールは, 自動データ作成技術や画像イン デックス自動生成技術により動画データベースを自動的 に構造化することができる．また，XML Webサービス 技術を活用して, 学生や研究者をはじめ多くのクライア ントやユーザーが, テキストや音声でコンテンツを検索, 閲覧することが可能である．高速ビデオカメラによる動 画やそれに伴うデータは, 教材や資料の作成, e ラーニ ングにおけるストリーミングコンテンツの開発等に利用 されるが (Fig. 18), このような動画データベースをシ ステム化しておくことによって，いちいちビデオテープ を探したり，コピーしたりする煩雑なワークから開放さ れることが期待できよう.また，このようなデータベー スの活用は, 単独の研究室や研究機関にとどまる必要は 無く, インターネットを介して非常に広範囲のコンテン ツ流通を可能にすると考えられる. スポーツ関係で言え ば（例えば国立スポーツ科学センターが中心となって）, いつでもどこでも様々なスポーツに関連する動画コンテ ンツや関連するデータにアクセスすることが可能になる 日も，そう遠くではないはずである.

\section{5. おわりに}

高速ビデオカメラの発達により, 全く新しい未知の映 像や，これまで見たくても見えなかった映像を見ること が可能になってきている. なにはともあれ，関心のある 現象を, 直接, 映像で見えるということは面白いことで あり，ありがたいことでもある．スポーツは本質的に運 動が不可欠であり, その映像は非常に重要な意味を持つ といえる. 今後, もっと高性能で高解像度の高速ビデオ カメラ等が開発されてくると予測されるが, それに伴っ て新しい発見や創造が生まれてくる事が期待され，ス ポーツ関係者は高速ビデオカメラから目を離せないと いっても過言ではないだろう.

謝辞

本稿で用いた画像やデー夕等の資料は，他の研究機関

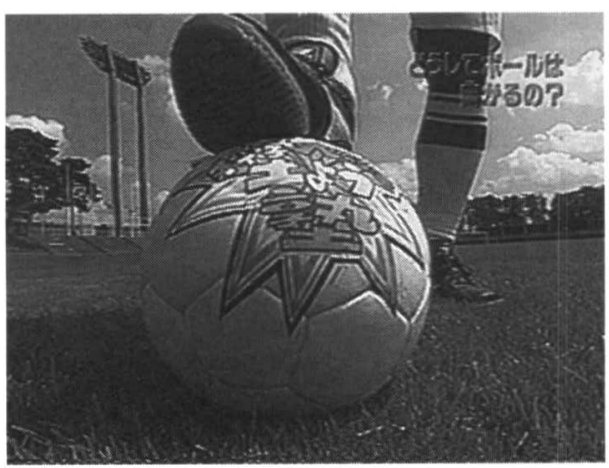

Fig. 18 An example of educational program using high speed video image. (Japan Broadcasting Corp.) 
とのコラボレーションによるものや，提供して頂いたも のが少なくない。この場を借りて，アシックス株式会社, フォトロン株式会社, フルーエント株式会社, エムエス シーソフトウェアー株式会社, シェフィールド大学, 名 古屋大学, 日本放送協会（NHK）に心から感謝致しま す.

\section{参考文献}

1）浅井武, 布目寛幸, 岩波科学ライブラリー 見方が変わるサッ カーサイエンス，(2002)，岩波書店.

2 ）浅井武，布目寛幸，星川佳広，橋詰謙，西脇剛史，浅井武監 修, ファンタジスタの科学, (2002), 光文社.

3) T. Nishiwaki, N. Nakabe, Numerical design of running shoes based on human response, The engineering of sport, $4, \mathrm{~S}$.
Ujihashi and S. J. Haake Ed., Blackwell Science, (2002), pp 393- 399 .

4）阿江通良, 藤井範久, スポーツバイオメカニクス 20 請, (2002), 朝倉書店.

5 ）深代千之，柴山明，スポーッ基礎数理ハンドブック，(2000）, 朝倉書店。

6) H. Nunome, T. Asai, Y. Ikegami, S. Sakurai, Threedimensional kinetic analysis of side-foot and instep soccer kicks, Med. Sci. Sports Exerc., 34, (2002), pp 2028- 2036.

7 ) T. Asai, M. J. Carre, T. Akatsuka, S. J. Haake, The curve kick of a football, I : impact with the ball, Sports Engineering, 5 , (2002), pp 183-192.

8 ) M. J. Carre, T. Asai, T. Akatsuka, S. J. Haake, The curve kick of a football, II : flight through the air, Sports Engineering, 5, (2002), pp 193-200. 


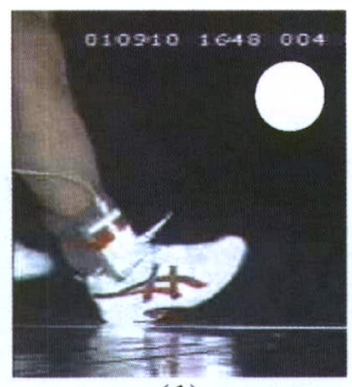

(1)

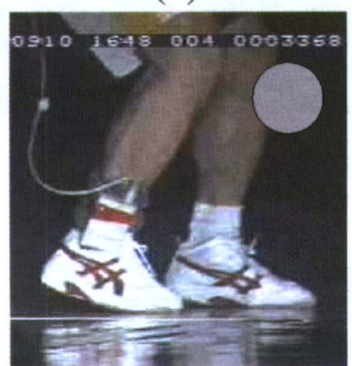

(4)

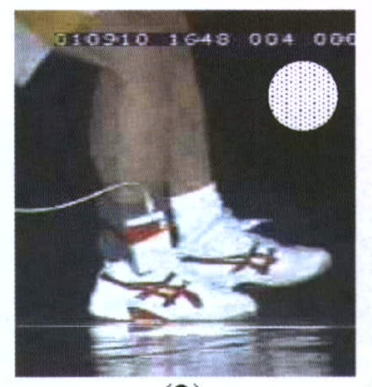

(2)

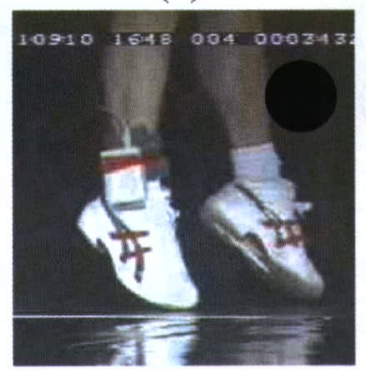

(5)

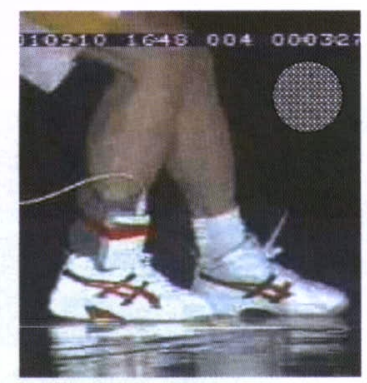

(3)

(a) バレーボールのスパイク時におけるジャンプ動作の高速ビデオ画像（アシックス株式会社）

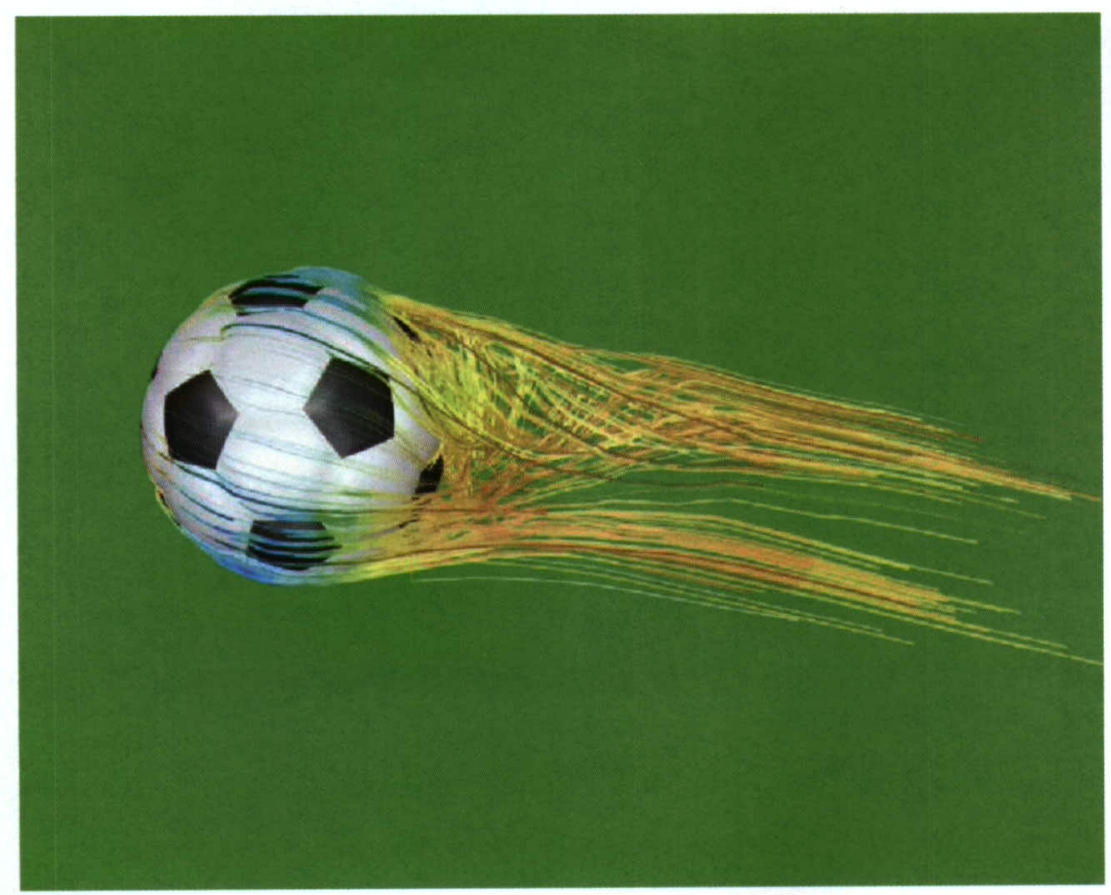

(b) サッカーボール周りの数值流体解析（フルーエント社） 